\title{
History and Relevance of Patronage, the Civil Service Reform and the Pendleton Act: The Rationale for Congressional Intervention
}

\author{
Robert Knox \\ Texas Southern University \\ E-mail: po_officer@yahoo.com/robert.knox @hcjpd.hctx.net \\ Michael O. Adams \\ Texas Southern University \\ E-mail: adams_mo@tsu.edu
}

Gbolahan S. Osho

Prairie View A\&M University

E-mail: gsosho@pvamu.edu

Received: March 18, 2017 Accepted: April 11, 2017 Online published: May 3, 2017

doi:10.5296/jpag.v7i2.10950

URL: https://doi.org/10.5296/jpag.v7i2.10950

\begin{abstract}
The ownership of land determined ones importance. However, the church was one of the largest single property holders in Italy. By the $11^{\text {th }}$ century, Bishops were competing with wealthy rural families to become patrons" of local land - owners. To combat the political problems in 1867 The Tenure of Office Act was passed during Andrew Jackson term; Congress passed the Act in an effort to secure a greater role in the appointive process. The act specific that those appointed with the advice and consent of the Senate could only be removed from office with the Senate's approval. Hence, the goal of this research is to examine the implications of political pressure on the evolutionary process with new emergent paradigm characterized by three anti-government values: personal accountability limited and decentralized government, and community responsibility for delivery or social services.
\end{abstract}


Keywords: Patronage, political parties, the Pendleton Act, Civil Service Reform

\section{Introduction}

Patronage was a practice of social institution throughout the early modern Europe, probably Peeking in importance between $14^{\text {th }}$ and $17^{\text {th }}$ centuries. It was nearly impossible, to determine specific origin of the tradition. Cicero thought that the origins of Rome or brought to Rome by Romulus himself. Early patronage was associated with the church, which was a result of the power Episcopal political influence in central Italy. The ownership of land determined ones importance. However, the church was one of the largest single property holders in Italy. By the $11^{\text {th }}$ century, Bishops were competing with wealthy rural families to become patrons" of local land - owners.

According to Biagioli patronage was not an option. It was the key to social status and it could lead to a career with social mobility were a person becomes involved with a network of patronage relationship. Dresang defines patronage as the "treatment of jobs, contracts and similar benefits as goods given to political supports of parties and elected officials". Official in local government began using the patronage system to build and maintain political machines. States and local government relied on bloc voting by groups and used the patronage appointments as rewards for those able to deliver bloc of votes. Lincoln felt compelled to use his appointive powers aggressively and strategically. Lincoln was concerned with unity, out of 1,639 Lincoln fired 1,457 appointed positions and rehired with patronage from his campaign. However, during the Lincoln administration the patronage system was so prevalent that it was considered a joke. Patronage power was a valuable prize.

During the last half of the nineteenth century there were several political battles for patronage appointment power in the house. To combat the political problems in 186, The Tenure of Office Act was passed during Andrew Jackson term; Congress passed the Act in an effort to secure a greater role in the appointive process. The act specific that those appointed with the advice and consent of the Senate could only be removed from office with the Senate's approval. The Act passed over the veto of President Andrew Jackson on March 2, 1867. When the Senate is not in session, the act allows the President to suspend an official, but if the Senate upon its reconvening refused to concur in the removal, the official must be reinstated in his position. Hence, the goal of this research is to examine the implications of political pressure on the evolutionary process with new emergent paradigm characterized by three anti-government values: personal accountability limited and decentralized government, and community responsibility for delivery or social services.

Also, during President Andrew Jackson term was responsible for introducing the Spoils System to the United States. Jackson calm that he would bring a new element to U.S. politics. Jackson appealed to the newly enfranchised segment of the electorate, white males who did not meet the pervious test for owning property and or earning above a stated level of income. When Jackson was in office he replaced $20 \%$ of the senior positions. Over half of the senior civil servant came from families with fathers who had high-status occupations and almost all 
others were sons of artisans, teachers, and shopkeepers. Women were not allowed to work in political position even clerk positions were given to men. Jackson would help his supports by showing them favors with jobs. Jackson actions contributed to the saying of "to the victory belongs the spoil".

\section{Prior Research}

The spoils system was defined as informal or formal practice by which the party in power, perhaps after winning an election, monopolizes prerequisites and government jobs with direct politically motivated appointments. The term "spoils" refers to luxury gains resulting from any kind of victory. Proponents of such a practice consider official position as rewards, which are given to loyal individual supporters. However, the slogan actually belonged to Senator Williams L Marcy of New York. The widespread, visible use of the spoil in the federal government came with the election of President Abraham Lincoln. Lincoln was confronted with the problems with the Civil War and the needs for building and stabilizing his new political party.

Furthermore, Lincoln primary concern was maintaining unity, rather than for securing competence. The ingredient that led to the demise of the spoil system was the resistance to the political machines and the newly arrived immigrant groups. At the forefront of change were a group of prominent Eastern personalities, some whom attacked the patronage system as the jugular of the political machines and some of who had been active abolitionists who saw spoils yet another means of curtailing individual freedom. Reformers wanted the system to return back to what they call the good old days before the Jacksonian democracy and the industrial revolution - das when men with their background, status and education were obvious leaders in the community.

During this time when the Reform movement was in the process of changing the political system a number of civil service reform associations emerged. One of the first organizations was establish in 1877, called the National Civil Service Reform League, in 1881. Part of the motivation for the development for a Reform System was the concern about the emergence of the new political force. With the emerge of this new system coming into power, the wealthy began to feel threaten by a mercantilist, commercially based class that was growing increasingly wealthy and able to purchase the land, titles and status that had traditionally been matter of birthright. The National Civil Service Reform League wanted to base civil service employment on merit and define merit in terms of formal education and performance on examinations.

\section{Policy Origination and the Pendleton Act}

Senator George H. Pendleton, a Democrat from Ohio designed a draft legislature to end the spoils system. Pendleton work failed at first; due to those in a position to help were benefiting from the spoils system and did not want a change. But, after the assassination of President James A Garfield, congress passed the Pendleton Act, which established the Merit System of public personnel administration in the United States. The Pendleton Act classified certain jobs, removed them from the patronage ranks, and set up a Civil Service Commission to administer 
a system based on merit rather than political connections. As the classified list was expanded over the years, it provided the American people with a competent and permanent bureaucracy. The Pendleton Act of 1883 was an act to regulate and improve the civil service of the United States. Sec 2 of the Pendleton Act states that "to aid the President, as he may request, in preparing suitable rules for carrying this act into effect, and when said rules shall have been promulgated it shall be the duty of all officers of the United States in the department and officers to which any rules may relate to aid, in all proper ways, in carrying said rules, and any modifications thereof, into effect". Also, Sec 2 states that first "competitive examinations for testing fitness of applicants for the public service now classified or to be classified hereunder.

Such examinations shall be practical in their character, and so far as may be shall relate to those matters which fairly test the relative capacity and fitness of the persons examined to discharge the duties of the service into which they seek to be appointed. The Pendleton Act states that no person in the public service is for that reason under any obligation to contribute to any political fund, or to render any political service, and that he will not be removed or otherwise prejudiced for refusing to do so. Also, no person in said service has any rights to use his authority or influence to coerce the political action of any person or body. There shall be non-competitive examinations in all proper case before the commission, when competent persons do not compete, after notice has been given of the existence of the vacancy, under such rules as may be prescribed by the commissioners as to the manner of giving notice. The spread of the merit system to other jurisdictions in the United States took place in spurts. New York and Massachusetts, supplied most of the leadership in civil service reform movement. However, there was little movement among the local and state level until the progressive movement attacked political machines in the Midwest.

The acceptance of the merit system concept was acceptance of Woodrow Wilson's. Wilson was a reform advocate and he served as president of the National Civil Service Reform League. Wilson believed that there should be a base distinction between politics involved values, conflicts, and compromise, and the output of politics was public policy. On the other hand Administration looked at the system as technique, process and science. The main objective for administration was to implement public policy. Nearly a century of public personnel management, guided by the desire to create a system of neutral competence and political responsiveness accomplished through selection on the basis of merit and protection of employees from improper political pressure, now seems to many a quaint but definitely outdated approach to staffing government (civil service reform).

In the place of the merit system of the past, today's reformers are calling for public personnel management systems based on selected principles derived from business, which emphasize the ability or senior - level managers to direct and control the activities of subordinates (C.S.R.), often giving those same managers greater freedom from political control and oversight and the opportunity to be entrepreneurial (C.S.R). Based on this premise, the scientific management movement attempted to build on the separation of politics and administration begun by the merit system. A German sociologist name Max Weber, viewed bureaucracies as structures that identify and arrange the specialized assignments that need to 
be complete if the organization is to achieve its goals and objectives. Weber believed that who ever, occupies a given position in an organization is responsible for the task assigned to that position. Fredrick Taylor began his work and studies of the scientific management during 1870 s and 1880s. Taylor's studies were consistent with Weber's theory and had a major impact on approaches and practices used in personnel management. Taylor conducted experiments in steel plants in Midvale and Bethlehem and he developed the scientific management methods.

Wilson mainly focused on the analysis of work, and he believe one could be scientifically determine the single best way of designing jobs in order to accomplish organization goals. Weber advocated a "systematic observation, classification, and tabulation of job activities and then the design of task according to the motions and capacities of humans and equipment". But, Wilson's greatest contribution to the industrial industry was the assembly line technology. Taylor's emphasis was in an extreme way on tasks rather than employees. Taylor's theory has been criticized and new approaches have emerged. However, Taylor and his theory were successful in increasing efficiency and productivity in organization where his methods were used. Taylor's work left important legacies, his work help to define positions, job duties and responsibility. There was another study done on the principle of scientific management. According to professor Elton Mayo of the Harvard Business School and some of his colleagues, did research on working behaviors in different companies. The research indicated, productivity increased when workers acted as a team and cooperated spontaneously (Dresang pg 90). Mayo research was credit with creating the human relations school and the study of the industrial sociology.

According to Mayo "the goal of the human relations approach is to design the work environment, orient supervision, and otherwise shape organizations to that employees have high morale and positive attitude about their jobs and about coworkers" (Dresang pg 90). However, Abraham Maslow expanded on the need for individual needs at work. According to Maslow "human needs are multiple and individuals work to satisfy those in a specific sequence" (Dresang pg 90). Maslow believed that over a life time of working a person would seek or achieve several different stages at work. Maslow theories or hierarchical sequences are Physiological needs, Need for safety, Love and belongingness, Self and group esteem and Self - actualization. Despite critics and lack of verification of Maslow hierarchy of needs, it has considerable intuitive appeal. "His thinking has a great influence on personnel management. Minimum wage and due process laws address the physiological and security needs identified by Maslow, although in fact these components of personnel systems have their origins more in public policies than in scholarly theories.

Other personnel management practices more directly draw from Maslow and other theories. Job enrichment and participatory management are based on recognition of employee aspirations for interesting and fulfilling work and for sharing and interacting with other workers" (Dresang pg 91). The major objective of public personnel management is to anticipants its employees needs in a timely and accurate way, update equipment with new technological as needed, identifies and hire competent people and "compensate workers in ways that perceive as fair and rewarding performance" (Dresang pg 307). Organization's 
Executive believes that their employees will be more productive and the organization will reach its goals. However, sometimes even the best plans still fall short in accomplishing the needs of employees and this can distract from the productivity of any company.

\section{Implication on Public Personnel Management}

Contemporary public personnel management differs from the past because it is characterized by two emergent alternatives to traditional civil service systems for delivering public services: alternative mechanisms and flexible employment relationships. These options are not new, but they are more common place then before. When new public programs are designed, these alternatives have largely supplanted tradition public program delivery by "permanent" civil service employees hired through appropriated funds. Historically, the assumption was that public services would be delivered by a staff of career civil service employees, working within the structure of centralized public agencies budgeted with appropriated funds. Today, none of these are true - public programs are more than likely performed by alternative organizations or mechanisms rather than by public agencies and when public agencies are used, they are more likely to be staffed by contingent workers hired through flexible employment mechanisms rather than permanent employees protected by civil service regulations and collective bargaining agreements" (Kilborn, 1995)

When a conflict between management and employees arises, management will start negotiation sessions to come to an agreement to resolve the problem. This process is called collective bargaining. "Collective bargaining is specifically industrial relations mechanism or tool, and is an aspect of negotiation, applicable to the employment relationship. As a process, the two are in essence the same, and the principles applicable to negotiations are relevant to collective bargaining as well. However, some differences need to be noted.

In collective bargaining the union always has a collective interest since the negotiations are for the benefits of several employees. Where collective bargaining is not for one employer but for several, collective interests become a feature for both parties to the bargaining process. In negotiations in non-employment situations, collective interest are less, or non-existent, except when states negotiate with each other. Further, in labour relations, negotiations involve the public interest such as where negotiations are on wages which can have an impact on prices. This is implicitly recognized when a party or the parties seek the support of the public, especially where negotiations have failed and work disruptions follow. Governments intervene when necessary in collective bargaining because the negotiations are of interest to those beyond the parties' themselves. In collective bargaining certain essential conditions need to be satisfied, such as the existence of the freedom of association and a labor law system. Further, since the beneficiaries of collective bargaining are in daily contact with each other, negotiations take place in the background of a continuing relationship which ultimately motives the parties to resolve the specific issues.

Unfortunately the term "bargaining" implies that the process is one of haggling, which is more appropriate to one-time relationships such as a one - time purchaser or a claimant to damages. While collective bargaining may take the form of haggling, ideally it should involve adjusting the respective positions of the parties in way that is satisfactory to all. 
Collective bargaining could also, be defined as negotiations relating to the terms of employment and conditions of work between an employer, a group of employers or an employer' organization on the one hand, and representative workers' organizations on the other, with a view to reaching agreement. There are several essential features of collective bargaining, all of which cannot be reflected in a single definition or description of the process:

i. It is not equivalent to collective agreement because collective bargaining refers to the process or means, and collective agreements to the possible results, of bargaining. Collective bargaining may not always lead to a collective agreement.

ii. It is a method used by trade unions to improve the terms and conditions of employment of their members.

iii. It seeks to restore the unequal bargaining position between employer and employee.

iv. Where it leads to an agreement, it modifies, rather than replaces, the individual contact of employment, because it does not create the employer-employee relationship" (Silva 1996).

The merits of collective bargaining have been argued by both opponents and proponents of the process; the former maintain that it deprives the worker of his individual liberty to dispose of his service, while the latter point out that without the union's protection the worker is subject to the dictation of the employer. As an essential process in labor relations, collective bargaining was first developed in Great Britain in the $19^{\text {th }}$ cent. It has since become an accept practice in most Western counties with a high level of industrialization. The National Labor Relations Act of 1935, known as the Wagner Acts, established the right to collective bargaining in United States (Columbia Encyclopedia, Sixth Edition, 2001).

Before the Wagner Act, the rights of workers were protected by the National Industry Recovery Act of 1933. In 1935, the Supreme Court declared the NIRA unconstitutional. By doing so, workers lost their rights to join unions of their choice and to bargain collectively. In 1935 the unemployment rate was over $21 \%$ and more than $50 \%$ lived in poverty as we measure it today. Large employers were said to have immense control over their workers who had at best, one single place to work. Those workers were paid less than then their economic contribution measure by their productivity. Before the Wagner Act, the federal government had refrained from supporting collective bargaining over wages and working conditions and from facilitating growth of trade unions. The new law marked a significant reversal of this attitude. American Federal of Labor and CIO took advantage of governmental encouragement by carrying out nationwide organizational campaigns.

The Wagner Act was sponsored by Senator Robert F. Wagner, from New York and was passed in July 1935 with firm support from Franklin D. Roosevelt. The act is more commonly known as the National Relations Act. Some say the NLRA is the single most important piece of labor legislation engaged in interstate commerce. The general objective is to guarantee employees the "right to self-organization, to form, join, or assist labor organizations, to bargain collectively through representatives of their own choosing, and to engage in 
concerted activities for the purpose of collective bargaining or other mutual aid and protect" New deal legislation designed to protect workers' right to unionization -implements the national labor policy of assuring free choice and encouraging collective bargaining as a means of maintaining industrial peace - Primary law governing relations between unions and employers in the private sector established the federal government as the regulator and ultimate arbitrator of labor relations (free essay.com). "However, this generally applies to all employers involved in interstate commerce other than airlines, railroad, agriculture, and government. Through the years, Congress has amended the Act and the Board and courts have developed a body of law from the statute" (Reynolds, 1979).

Since the end of the Civil War until the mid $20^{\text {th }}$ century, minorities were discriminated in several different forms and it was the pillar of American life. "No protected racial minorities and women from biased employers, who were pass over a black worker in favor of a white worker or to reserve better paying jobs for white men only. Women were even barred by law from various job professions. The modern day civil rights movement that began officially with the formation of the NAACP in 1909, U.S. Supreme Court's Brown v. Board of Education decision in 1954, which declared racially segregated public schools unconstitutional" (ACLUFL pg1).

The term affirmative action was first used by President John F. Kennedy; in a 1961 executive order designed to encourage contracts on projects financed with federal funds to racially integrate their workforces. Kennedy's executive order declared that federal contractors should "take affirmative action to ensure that application is employed, and employees are treated during their employment, without regard to race, creed, color of national origin." (Encarta pg 2) Years later, Congress passed the Civil Rights Act of 1964 "the first truly equal rights law enacted since Reconstruction. Title VII of that law prohibits employment discrimination, in both the public and private sectors, based on race, generation, national origin or religion." (ACLUFL pg 1)

According to Paul Finkelman, the original goal of the civil rights movement had been color blind laws. However, many people believe that simply ending a long-standing policy of discrimination did not go far enough. Some believed that Affirmative Action or some law was needed to increase equality between the races was necessary. Most believe that Affirmative Action Act would give minorities an even chance applying for a job and receiving a promotion at work. President Lyndon Johnson stated in a speech at Howard University, "you do not take a person who, for years, has been hobbled by chains and liberate him, bring him up to the starting line of a race and say, you are free to compete with all the others; and still justly believe that you have been completely fair." (AA pg 2)

Also, President Nixon was the first President to implement "federal policies designed to guarantee minority hiring." (AA pg 2) President Nixon designed this Act, due to several reports of racial discrimination of hiring and promotions denial in several companies, based mostly on religion or the color of skin. In 1972, "affirmative action became an inflammatory issue. The Civil Rights Act of 1964 already had made something called affirmative act a remedy federal courts could impose on violators of the Act. Likewise, after 1965 federal 
contractors had been subject to President Lyndon Johnson's Executive Order 11246, requiring them to make "affirmative act" to make sure they were not discriminating. But what did this 1965 mandate amount to? The Executive Order assigned to the Secretary of Labor the job of specifying rules of implementation. Plus the federal courts were enforcing the Civil Rights Act against discriminating companies, unions and other institutions, the Department of Labor mounted an ad hoc attack on the construction industry by cajoling, threatening, negotiating, generally strong-arming reluctant construction firms into series of region-wide plans in which they committed themselves to numerical hiring goals. Through these contractor commitments, the Department could indirectly pressure recalcitrant labor unions, who supplied the employees at the job sites.

While the occasional court case and government initiative made the news and stirred some controversy, affirmative act was pretty far down the list of public excitement until the autumn of 1972, when the Secretary of Labor's revised Order No. 4 fully implementing the Executive, landed on campus by the way of directives from the Department of Health, Education, and Welfare. Its predecessor, Order No. 4, first promulgated in 1970, cast a wide net over American institutions, both public and private.

By extending to all contactors the basic apparatus of the construction industry plan the Order imposed a one-size-fits system of underutilization analysis goals, and timetables on hospitals, banks, trucking companies, steel mills, printers, airlines-indeed, on all the scores of thousands of institutions with a particularly voluble and articulate constituency, namely, and American Universities." (AA pg 2) Many other different polices have went under the label of Affirmative Act and many institutions, courts decisions and private agencies have been involved in interpreting the different labels. There is no one best way to define the meaning of Affirmative Act.

The only thing that can be done is to examine the particular the concepts, the intentions and the actual effects. However, there is a negative side to having the Affirmative Act. Since the 1960s, Affirmative Action has been a highly controversial topic. Critics have stated that Affirmative action police gave preferential treatment to based on being in a minority group, which violates the law, which states that everyone is equal under the law. Affirmative Action discriminates against a group of people, based on what happen to another group from the past. In other words Affirmative Action is a form of reverse discrimination against whites from better jobs and promotions. Affirmative Action gives an unfair advantage to minorities when enrolling for College. For example: in a recent court case, "several Caucasian students are suing the University of Michigan in the Supreme Court on the grounds of racial discrimination in the admission process. Officially called Grutter vs. Bollingers, the students in the case discovered that several African American applicants with less impressive records of academic performance were accepted to the school, though the white students whose achievements had been more notable were turned down.

Upon investigation, it was discovered that the University of Michigan integrates Affirmative Action policies into its admissions decisions. One possible source of points on their charts is belonging to an ethnic minority a feat for which someone may be awarded 20 points. Due to 
this point increase on race, it is believed that the African American students were accepted to the school and higher achieving white students were left out of the enrollment numbers"(AA PR pg 3). The University of Michigan stands by their decision on using Affirmation Action, the University Administrators, believe the Act will ensure equality in the education system. In another court case were Affirmative Action was found to be reverse discrimination was in the 1996 case Hopwood v. Texas, "a federal appeals court barred the University of Texas Law School from any consideration of race or ethnicity in its admissions decisions" (Encarta pg 6), due to non-black students applicants being rejected on the bases of Affirmative Action. Also, California, Texas, and Florida have put bans on Affirmative Action in public schools due to unfair advantages, given to minorities. Plus, if you are a minority you are more likely to receive financial aid, to help you get into college then Caucasian students. More federal courts are considering lawsuits from white student being denied admission into Colleges based on Affirmative Action programs. Some school programs have been invalidated on the grounds that reverse discrimination was proven in federal court. Affirmative Action is slowly being proven as a form of reverse discrimination

\section{Conclusion}

Finally, the last twenty years have marked the turning point in the evolution of public personnel management. At one point, the public personnel management was ruled by the equilibrium among competing pro-government values. However, in 1992, "strong political pressure to "do more with less" supplanted this evolutionary process with new emergent paradigm characterized by three anti-government values: personal accountability, limited and decentralized government, and community responsibility for delivery or social services.

The emergent paradigm has changed the role of the public personnel manager: from conflict resolution among competing values to implementation of contact compliance with legislative limits. Their role is changed more in the direction of their sector counterparts in that they are less responsible for resolving value conflicts than for increasing productivity as defined legislatively. Also, their role is diminished to extent that the value idealized by the paradigm shift assumes less of a role for public agencies and employees in the accomplishment of public objectives.

\section{References}

Affirmative Action.

http://encarta.msn.com/encyclopedia_761580666/Affirmative_Action.html

Alan Reynolds. (1979). What Do We Know About the Great Crash? National Review, November 9, 1979.

American Civil Service Liberties Union Of Florida.

http://www.aclufl.org/take_action/download_resources/info_papers/17.cfm

Charles, W. G. (2001). Civil Service Reform, the case of Georgia. pg 95 Columbia Encyclopedia, Sixth Edition. http://www.bartleby.com/65/co/collecti-b.html

Dennis, L. D. Public Personnel Management and Public Policy paperback, $4^{\text {th }}$ ed. 


\section{Macrothink}

Journal of Public Administration and Governance ISSN 2161-7104 2017, Vol. 7, No. 2

Donald, E. K., Beyond Civil Service: The Changing Faces of Public Personnel Management. http://www.fiu.edu/ klinger/beyondcs2.htm

Donald, E. K. Beyond Civil Service: The Politics of the Emergent Paradigm.

http://www.fiu.edu/ klinger/politics.htm

Donald, E. K., \& Mohamed, G. Sabet. Contemporary Public Human Resource Patronage, Civil Service, Privatization, and Service Contract. Free Essays. us - Wagner Act.

http://www.free-essays.us/dbase/c1/qbi75.shtml

Lucas Slominski, Tobiah Shafer, Jacob Schamp \& Kevin Manlte. Affirmative Action a policy revised.

Reynolds, A. (1979). What Do We Know About the Great Crash? National Review, November 9,

Silva, Sriyan de. Collective Bargaining Negotiations.

http://www.ilo.org/public/english/dialogue/actemp/papers/1998/srscbarg.htm

\section{Copyright Disclaimer}

Copyright for this article is retained by the author(s), with first publication rights granted to the journal.

This is an open-access article distributed under the terms and conditions of the Creative Commons Attribution license (http://creativecommons.org/licenses/by/4.0/). 